\title{
Article
}

\section{Podcasts for Learning English Pronunciation in Igboland: Students' Experiences and Expectations}

\author{
E.E. Mbah*, B.M. Mbah**, M.I. Iloene*** \\ Department of Linguistics, Igbo and other Nigerian languages, University of \\ Nigeria, Nsukka, Nigeria \\ G. Iloene**** \\ Department of Linguistics, Ebonyi State University, Abakaliki, Nigeria
}

*ezymbah @ yahoo.co.uk |**boniface.mbah @ unn.edu.ng |***modesta.iloene @ unn.edu.ng |****georgeiloene @ yahoo.com

\begin{abstract}
This paper studies students' experiences and expectations on the use of podcasts in learning English pronunciation in Igboland. The study is based on a survey where two universities were studied. A proportional sampling technique with the aid of a structured questionnaire was used to elicit information. The data gathered were analysed using mean, standard deviation, t-test, and ANOVA with the aid of Statistical tool for the Social sciences. The study concluded that the students agreed to the fact that podcasts improved their English pronunciation. The hypotheses tested showed that there was no significant difference in the use of podcasts with regard to the students' internet usage habits, language proficiency level, or gender. Thus, it was concluded that this technology was appropriate for second language learning.
\end{abstract}

Keywords: Podcasts, English pronunciation, Igboland.

\section{Introduction}

English is learned as a second language in Igboland (and all over Nigeria). Learning English in Nigeria is confronted with some challenges. One of the challenges according to Oluikpe (1978) is that English is not taught to solve the language problems relating to the linguistic peculiarities of Nigerian learners including the fact that rather than writing textbooks for commercial purposes as is customary in the country, they should be written for different language groups to solve their peculiar linguistic problems. Language teaching involves teaching pronunciation, vocabulary, grammar and the culture of the target language. The place of pronunciation in L2 teaching is often relegated when compared to grammar, vocabulary and culture (Lord, 2008). Part of the reason for the relegation is that many teachers assume that with more L2 input, students will learn pronunciation, or it will be acquired at a later stage.

Podcasts are among the new techniques and technologies which meet the learners' needs of having additional pronunciation input outside the classroom. The netgeneration students are often very busy and involve themselves in multitasking (Tapscott, 2009) and many of them have devices for playing audio files (Rainie \& Madden, 2005; Schmidt, 2008). These reasons combine to make it necessary for podcasts to be one of the tools used in delivering L2 materials to the students. Hence, 
Craig, et al. (2007) and Windham (2007) agree that many L2 learners find the use of podcasts motivating since many of them study through distant learning programs, and may not have enough time to attend language laboratory and classrooms regularly. Podcasts are important for teaching and learning phonetics. Knight (2010) avers that podcasts help in alleviating the difficulties students encounter in phonetics since they provide the students with an alternative audio-based exercise material against the paper-based ones. The report of Thorne and Payne (2005) of Duke University's iPod projects reveals that podcast-based projects in language classrooms are necessary in developing oral skills. Lord (2008) engaged his students (undergraduate Spanish Phonetics class) in a collaborative podcasting project. The students were divided into small groups and were made to create and maintain their own podcasts channel where they uploaded recordings for their members to comment on. Pre- and post- semester attitudes and pronunciation abilities were tested. The results showed that there was an improvement on the students' pronunciation even though the factor(s) that influenced the improvement cannot be pinpointed. On the other hand, Ducate and Lomicka (2009) tested the effectiveness of podcasting in honing American English students' pronunciation in German and French and records insignificant improvement although the students appreciated the tool. Knight (2010) investigated students' perception of podcasts in phonetics. The results showed that the students perceived podcasts to be useful in their learning of phonetics. In the same vein, Li (2012) examined the students' perception of podcasts and reports that the year 6 secondary school students perceived podcasts to be a useful tool which has enhanced their language skills. Chan, Chen, and Döpel (2011) studied two podcast projects organised at a university in Singapore, aimed to aid classroom instruction for Chinese and Koreans as a foreign language. They used a semi-structured interview to determine their perceptions of the podcasts' quality and usefulness. They observed that respondents who used podcasts on the move or outside their abodes had significant positive attitudes towards podcasts and were also found to be interested in podcast-based learning after being exposed to the podcast course. Hasan and Hoon (2013) reviewed twenty journal articles to establish the effects of podcasts on ESL students' language skills and attitude levels. They found out that podcasts greatly facilitate $\mathrm{L} 2$ pronunciation among other language skills.

\subsection{Purpose of the study}

The general objective of this study is to identify podcasts for learning English pronunciation by students in Igboland. Its specific objectives are contained in the subsequent research questions and hypotheses.

\subsection{Research questions}

The following research questions will be answered by the study:

1. How does the students' background regarding internet use or computer-assisted language learning (CALL) affect the use of ESL podcasts?

2. To what extent do the types of gadget students use for podcasts affect their interest in listening to podcasts?

3. How did students come to learn about podcasts?

4. Why do students listen to podcasts?

5. In what manner does listening to podcasts influence students' performance in English phonetics-related courses and their spoken English?

6. What are the students' experiences in using podcasts to learn English pronunciation?

7. What are the students' expectations in using podcasts to learn English pronunciation? 


\subsection{Research hypotheses}

The following seven null hypotheses were formulated and tested at 0.05 level of significance.

1. There is no significant difference in the mean ratings of the responses of male and female students regarding their internet or computer-assisted language learning usage for language learning.

2. There is no significant difference in the mean ratings of the responses of male and female students on the types of gadget that affect one's active use of podcasts.

3. There is no significant difference in the mean ratings of the responses of 100 , 200, 300 and 400 level students on the influences of students' background information on the knowledge of podcasts.

4. There is no significant difference in the mean ratings of the responses of male and female students on the students' reasons for listening to podcasts.

5. There is no significant difference in the mean ratings of the responses of 100 , 200, 300 and 400 level students on the influences of students' listening to podcasts on performance in English phonetics.

6. There is no significant difference in the mean ratings of the responses of 100 , 200, 300 and 400 level students on students' experiences in using podcasts to learning English pronunciation.

7. There is no significant difference in the mean ratings of the responses of male and female students' expectations in using podcasts to learn English pronunciation.

\section{Methodology}

This study adopted survey-based research. Five universities in the five major states that constitute Igboland were used for the study. One university from each state was taken. In a situation where there are two or more universities in a state, preference was given to a federal university. However, where there is no federal university of up to ten years of age, an older state university was chosen. The five universities selected were Abia State University, Umuahia; Ebonyi State University, Abakaliki; Imo State University, Owerri; Nnamdi Azikiwe University, Awka; and the University of Nigeria, Nsukka. A preliminary study carried out showed that only two universities made use of podcasts. The universities that made use of podcasts were the University of Nigeria, Nsukka, and Nnamdi Azikiwe University, Awka.

The population of this study was comprised of 4000 respondents, made up of students from each academic level. The proportionate sampling technique was used for the study. In using this technique, the $10 \%$ sample that was drawn from the population of 4000 students amounted to 400 .

\subsection{Data collection instrument}

The instrument used for data collection was a structured questionnaire. The questionnaire was made up of two parts. Part one comprising nine items to collect information on personal data, while part two, comprising 34 items, was structured into six sections enquiring about students' experience and expectations in using podcasts for learning English pronunciation. The response scale was as follows:

\begin{tabular}{|l|l|}
\hline Strongly Agree (SA) & 5 points \\
\hline Agree (A) & 4 points \\
\hline Undecided (UD) & 3 points \\
\hline Disagree (D) & 2 points \\
\hline
\end{tabular}




\begin{tabular}{|l|l|}
\hline Strongly Disagree (SD) & 1 point \\
\hline Total & 15 \\
\hline Mean for response scale & $15 / 5$ \\
\hline & $=3.00$ \\
\hline
\end{tabular}

\subsection{Data collection method}

The questionnaire was administered to the respondents and collected after one week. A total of 376 out of 400 copies of the questionnaire items were returned. It was these numbers that were analyzed to generate data used for answering the research questions and testing of the null hypotheses.

\subsection{Data analysis method}

The data collected from the respondents was analyzed using mean, standard deviation t-test and ANOVA statistics. SPSS was used also to ensure accuracy. The mean and standard deviation were used to answer the research questions. The mean for the response scale was 3.00 . The lower limit of the mean was 2.50 while the upper limit was 3.50 with an interval scale of 0.05 from the mean. Any item with a mean rating of 3.50 and above was regarded as "agreed" while any item with a mean rating less than 3.50 was regarded as "disagreed". The standard deviation was used to determine the closeness or otherwise of the opinions of the respondents from the group mean. The ttest and ANOVA statistics were used to test the five null hypotheses at a probability of 0.05 level of significance for the calculation of t-test and ANOVA statistics. In any hypotheses whose significance levels were less than or equal to the stated 0.05 level of significance, the null hypothesis was rejected, but if the levels were greater than an 0.05 level of significance, the null hypotheses were accepted.

\section{Results and discussion}

The results of the research questions and their corresponding hypotheses are presented and subsequently discussed in this section.

\section{Research Question One}

How does the students' background regarding internet use or computer-assisted language learning affect the use of ESL podcasts?

\section{Hypothesis One}

There is no significant difference in the mean ratings of the responses of male and female students regarding their internet or computer-assisted language learning usage for language learning.

The data for answering research question one and testing hypothesis one are presented in table 1 below.

\begin{tabular}{|c|l|l|l|l|l|l|l|l|}
\hline SN & $\begin{array}{l}\text { Students' use of the internet that } \\
\text { affects the use of ESL podcasts }\end{array}$ & XM & XF & XG & p-values & RQ & Ho \\
\hline 1 & $\begin{array}{l}\text { Searching internet information and } \\
\text { resources }\end{array}$ & 4.15 & 4.14 & $\mathbf{4 . 1 5}$ & 0.978 & Agree & NS \\
\hline 2 & $\begin{array}{l}\text { Accessing SLN courses and class } \\
\text { assignments }\end{array}$ & 4.24 & 4.47 & $\mathbf{4 . 3 6}$ & 0.005 & Agree & S* \\
\hline
\end{tabular}




\begin{tabular}{|c|c|c|c|c|c|c|c|}
\hline 3 & Making PowerPoint slides & 4.10 & 4.26 & 4.18 & 0.055 & Agree & NS \\
\hline 4 & Downloading online podcasts & 3.97 & 4.08 & 4.02 & 0.178 & Agree & NS \\
\hline 5 & Listening to online podcasts & 4.03 & 4.30 & 4.17 & 0.001 & Agree & S* \\
\hline 6 & $\begin{array}{l}\text { Posting comments to online group and social } \\
\text { networking }\end{array}$ & 4.10 & 4.33 & 4.22 & 0.009 & Agree & S* \\
\hline 7 & $\begin{array}{l}\text { Creating/working on webpage, journal and } \\
\text { weblog }\end{array}$ & 4.10 & 4.09 & 4.10 & 0.928 & Agree & NS \\
\hline 8 & Checking emails with different browsers & 4.12 & 4.06 & 4.09 & 0.502 & Agree & NS \\
\hline 9 & $\begin{array}{l}\text { Sharing ideas using e-learning forum } \\
\text { platform }\end{array}$ & 3.99 & 4.12 & 4.05 & 0.124 & Agree & NS \\
\hline
\end{tabular}

Table 1. Mean ratings and t-test statistics regarding the students' internet or computerassisted language learning usage $(N=376)(1)$.

The results presented in table 1 show that the grand mean values of the 9 items in the table ranged from 4.02 to 4.36 which are all greater than the cut-off point value of 3.00 on the 5-point rating scale. This indicates that the respondents agreed that all 9 items in the table are ways through which the internet or computer-assisted language learning affect their use of ESL podcasts.

The results of t-test statistics in the table reveal that, the p-values of items 2,5 and 6 were $0.005,0.001$ and 0.009 respectively which are less than a 0.05 level of significance. This implies that there are significant differences in the mean ratings of male and female students on the 3 items. On the other hand, the p-values of the remaining 6 items range from 0.55 to 0.978 which are greater than a 0.05 level of significance. This indicates that there are no significant differences in the mean ratings of the responses of male and female students on the six items.

Hence, the students' internet or CALL usage facilitates their motivation for using podcasts to improve their English pronunciation. One who does not know his/her way through the internet may find it difficult to search for suitable podcasts. This is not the case with these students since this buttresses Tapscott's (1999) view that this generation of students belong to the net-generation who involve themselves in multitasking and avail themselves of internet opportunities.

\section{Research Question Two}

What are the types of gadget that affect one's active use of podcasts?

\section{Hypothesis Two}

There is no significant difference in the mean ratings of the responses of male and female students on the types of gadget that affect one's active use of podcasts.

The data for answering research question two and testing hypothesis two are presented in table 2 below.

\begin{tabular}{|c|l|c|c|c|c|c|c|}
\hline SN & $\begin{array}{l}\text { Types of gadget that affect one's active } \\
\text { use of podcasts include: }\end{array}$ & XM & XF & XG & p-values & \multicolumn{2}{|c|}{ Remarks } \\
\cline { 5 - 8 } & & Ho \\
\hline 1 & The use of ipod/Mp3 player & 3.99 & 4.03 & $\mathbf{4 . 0 6}$ & 0.132 & Agree & NS \\
\hline 2 & The use of desktop computer & 3.98 & 3.94 & $\mathbf{3 . 9 6}$ & 0.566 & Agree & NS \\
\hline
\end{tabular}




\begin{tabular}{|c|l|c|c|c|c|c|c|}
\hline 3 & The use of laptop/notebook computer & 4.01 & 4.02 & $\mathbf{4 . 0 1}$ & 0.904 & Agree & NS \\
\hline 4 & The use of cell phone & 4.04 & 4.06 & $\mathbf{4 . 0 5}$ & 0.810 & Agree & NS \\
\hline 5 & $\begin{array}{l}\text { The use of Blackbery, Mp4 and other } \\
\text { personal digital assistant }\end{array}$ & 4.16 & 4.38 & $\mathbf{4 . 2 7}$ & 0.009 & Agree & S* \\
\hline 6 & The use of digital camera & 4.27 & 4.33 & $\mathbf{4 . 3 1}$ & 0.073 & Agree & NS \\
\hline 7 & The use of video camera & 4.34 & 4.55 & $\mathbf{4 . 4 5}$ & 0.010 & Agree & S* \\
\hline 8 & The use of webcam & 4.39 & 4.26 & $\mathbf{4 . 3 2}$ & 0.130 & Agree & NS \\
\hline
\end{tabular}

Table 2. Mean ratings and t-test statistics of the types of gadget that affect one's active use of podcasts $(\mathrm{N}=376)$.

For abbreviations see Note 1 below.

These results reveal that the respondents agreed that ipod/Mp3 players, desktop computers, laptop/notebook computers, cell phones, Blackberry, Mp4 and the likes, digital cameras, and webcams are the types of gadgets that affect active use of podcasts. Thus, portables devices for playing audio files are good for downloading and listening to podcasts (Rainie \& Madden, 2005; Schmidt, 2008). The extra input to support students in their learning can be accessed through the use of new mobile technologies (Ashby, Feguera-Clark, Seo, \& Yanagisawa, 2005; Stenson. Downing, Smith \& Smith 1992; Eskenazi 1999; Hardison 2004). thus helping students listen to their downloaded podcasts anywhere, anytime.

\section{Research Question Three}

How does the students' prior knowledge on podcasts influence their motivation?

\section{Hypothesis Three}

There is no significant difference in the mean ratings of the responses of $100,200,300$ and 400 level students on the influences of students' background information on the knowledge of podcasts.

The data for answering research question three and testing hypothesis three are presented in table 3 below.

\begin{tabular}{|c|c|c|c|c|c|c|c|}
\hline \multirow{2}{*}{ SN } & \multirow{2}{*}{$\begin{array}{l}\text { Influences of students' background } \\
\text { information on the knowledge of } \\
\text { podcasts include: }\end{array}$} & \multirow{2}{*}{$\begin{array}{l}\text { Total Sum } \\
\text { of Square }\end{array}$} & \multirow{2}{*}{$\begin{array}{l}\text { Mean } \\
\text { Square }\end{array}$} & \multirow{2}{*}{$\begin{array}{l}\text { P- } \\
\text { values }\end{array}$} & \multirow{2}{*}{$\mathbf{X G}$} & \multicolumn{2}{|c|}{ Remarks } \\
\hline & & & & & & $\mathbf{R Q}$ & Ho \\
\hline 1 & $\begin{array}{l}\text { knowledge of podcasts was through my } \\
\text { teacher }\end{array}$ & 231.104 & 2.356 & 0.009 & 4.16 & Agree & s* \\
\hline 2 & $\begin{array}{l}\text { knowledge of podcasts was through a } \\
\text { friend }\end{array}$ & 198.040 & 0.524 & 0.136 & 3.95 & Agree & NS \\
\hline 3 & $\begin{array}{l}\text { knowledge of podcasts was through my } \\
\text { interest in acquiring the native speaker's } \\
\text { pronunciation }\end{array}$ & 239.436 & 1.243 & 0.119 & 4.19 & Agree & NS \\
\hline 4 & learning about podcasts is necessary & 222.202 & 1.534 & 0.100 & 4.37 & Agree & NS \\
\hline
\end{tabular}

Table 3. Mean ratings and analysis of variance (ANOVA) on the influences of students' background information on the knowledge of podcasts $(N=376)$.

The results presented in table 3 show that the grand mean values of the 4 items in the table range from 3.95 to 4.37 which are all greater than the cut-off point value of 3.00 
on the 5-point rating scale. This indicates that the respondents agreed that all 4 items in the table have influenced the students' background knowledge about podcasts.

The results of Analysis of variance (ANOVA) in the table reveal that, the p-values of items 1 was 0.009 which is less than a 0.05 level of significance. This shows that there are significant differences in the mean ratings of students at all levels of education on item 1 . On the other hand, the p-values of the remaining 3 items ranged from 0.100 to 0.136 which are greater than a 0.05 level of significance. This indicates that there are no significant differences in the mean ratings of the responses of students at all levels of education on the 3 items. This finding shows that irrespective of the source of information, the students are willing to improve their pronunciation. Similar studies have shown that students desire to acquire native-like pronunciation irrespective of where the information is taken from (Derwing and Munro, 2003; Kang, 2010; Scales, Wennerstrom, Richard, \& Wu, 2006; Timmis, 2002). This may be one of the reasons why they were willing to access podcasts and listen to them without being monitored.

\section{Research Question Four}

Why do students listen to podcasts?

\section{Hypothesis Four}

There is no significant difference in the mean ratings of the responses of male and female students on the students' reasons for listening to podcasts.

The data for answering research question four and testing hypothesis four are presented in table 4 below.

\begin{tabular}{|c|l|c|c|c|c|c|c|}
\hline SN & $\begin{array}{l}\text { Students' reasons for listening to } \\
\text { podcasts are: }\end{array}$ & XM & XF & XG & p-values & RQ & Ho \\
\hline 1 & Vocabulary & 4.37 & 4.28 & 4.33 & 0.280 & Agree & NS \\
\hline 2 & Pronunciation & 4.25 & 4.20 & 4.23 & 0.582 & Agree & NS \\
\hline 3 & lomposition & 4.28 & 4.15 & 4.22 & 0.059 & Agree & NS \\
\hline 4 & Grammar & 3.96 & 4.04 & 4.01 & 0.375 & Agree & NS \\
\hline 5 & Logical reasoning & 4.42 & 4.47 & 4.45 & 0.483 & Agree & NS \\
\hline 6 & Socialisation & 4.04 & 3.88 & 3.96 & 0.068 & Agree & NS \\
\hline 7 & Lectures & 4.09 & 3.94 & 4.00 & 0.207 & Agree & NS \\
\hline 8 & Entertainment & 4.29 & 4.18 & 4.23 & 0.064 & Agree & NS \\
\hline
\end{tabular}

Table 4. Mean ratings and t-test statistics regarding the students' reasons for listening to podcasts $(\mathrm{N}=376)$.

The results presented in table 4 show that the grand mean values of the 8 items in the table range from 3.96 to 4.45 which are all greater than the cut-off point value of 3.00 on the 5-point rating scale. This indicates that the respondents agreed that all the 8 items in the table are reasons for listening to podcasts.

The results of Analysis of variance (ANOVA) in the table reveal that, the p-values of the 8 items range from 0.059 to 0.483 which are greater than a 0.05 level of significance. This indicates that there are no significant differences in the mean ratings of the responses of students' reasons for listening to podcasts at all levels of education on the 
8 items. The results of research question four show that although many students were introduced to podcasts first by their phonetics teachers, as revealed in the results of research question three, the primary essence of a phonetics teacher introducing his students to podcasts may be to improve their pronunciation, but as the students started listening to podcasts, they discovered that in addition to good pronunciation, podcasts are also useful in areas of vocabulary development, composition, grammar, logical reasoning, socialisation, lectures and entertainment.

\section{Research Question Five}

How does listening to podcasts influence students' performance in English phoneticsrelated courses and their spoken English?

\section{Hypothesis Five}

There is no significant difference in the mean ratings of the responses of $100,200,300$ and 400 level students on the influences of students' listening to podcasts on performance in English phonetics.

The data for answering research question five and testing hypothesis five are presented in table 5 below.

\begin{tabular}{|c|c|c|c|c|c|c|c|}
\hline \multirow{2}{*}{ SN } & \multirow{2}{*}{$\begin{array}{l}\text { Influence of listening to podcasts on } \\
\text { performance in phonetics include: }\end{array}$} & \multirow{2}{*}{$\begin{array}{l}\text { Total Sum } \\
\text { of Square }\end{array}$} & \multirow{2}{*}{$\begin{array}{l}\text { Mean } \\
\text { Square }\end{array}$} & \multirow{2}{*}{$\begin{array}{l}\text { P- } \\
\text { values }\end{array}$} & \multirow{2}{*}{ XG } & \multicolumn{2}{|c|}{ Remarks } \\
\hline & & & & & & $\mathbf{R Q}$ & Ho \\
\hline 1 & $\begin{array}{l}\text { Podcasts have positively affected scores in } \\
\text { English Phonetics courses }\end{array}$ & 193.660 & 0.915 & 0.310 & 4.15 & Agree & NS \\
\hline 2 & $\begin{array}{l}\text { Podcasts have improved oral English } \\
\text { performance }\end{array}$ & 196.359 & 0.545 & 0.035 & 4.35 & Agree & s* \\
\hline 3 & 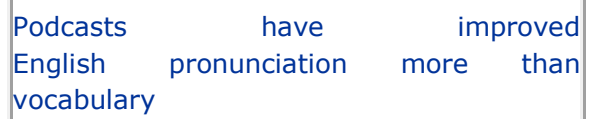 & 206.231 & 1.111 & 0.108 & 4.05 & Agree & NS \\
\hline 4 & \begin{tabular}{|lrr} 
Podcasts & have & improved \\
English & pronunciation & more \\
than grammar & &
\end{tabular} & 186.245 & 0.464 & 0.425 & 4.24 & Agree & NS \\
\hline 5 & $\begin{array}{llr}\begin{array}{l}\text { Podcasts } \\
\text { pronunciation }\end{array} & \text { have } & \text { improved } \\
\text { reasoning } & & \text { than logical }\end{array}$ & 226.926 & 0.823 & 0.254 & 3.89 & Agree & NS \\
\hline
\end{tabular}

Table 5. Mean ratings and Analysis of variance (ANOVA) on the influences of students' listening to podcasts on performance in English phonetics $(N=376)$.

The results presented in table 5 show that the grand mean values of the 5 items in the table range from 3.89 to 4.24 which are all greater than the cut-off point value of 3.00 on 5-point rating scale. This indicates that the respondents agreed that all 5 items in the table influence them toward listening to podcasts on performance in English phonetics.

The ANOVA analysis reveals that the p-value of item 2 was 0.035 which is less than a 0.05 level of significance. This indicates that there are significant differences in the mean ratings of students at all levels of education on item 2. On the other hand, the pvalues of the remaining 4 items range from 0.108 to 0.425 which are greater than a 0.05 level of significance. This range indicates that there are no significant differences in the mean ratings of the responses of students at all levels of education on the 4 items. 
The results above show that the teachers' primary aim of exposing them to podcasts was achieved. Hence they acknowledged the fact that thay had gained more knowledge in pronunciation than in any other aspect of language acquisition.

\section{Research Question Six}

What are the students' experiences in using podcasts to learn English pronunciation?

\section{Hypothesis Six}

There is no significant difference in the mean ratings of the responses of $100,200,300$ and 400 level students on students' experiences in using podcasts to learning English pronunciation.

The data for answering research question six and testing hypothesis six are presented in table 6 below.

\begin{tabular}{|c|c|c|c|c|c|c|c|}
\hline \multirow{2}{*}{ SN } & \multirow{2}{*}{\multicolumn{2}{|c|}{\begin{tabular}{|l}
$\begin{array}{l}\text { Students' experiences in using Total Sum of } \\
\text { podcasts to learning English } \\
\text { pronunciation include: }\end{array}$ \\
pquare
\end{tabular}}} & \multirow{2}{*}{$\begin{array}{c}\text { Mean } \\
\text { Square }\end{array}$} & \multirow{2}{*}{$\begin{array}{c}\text { p- } \\
\text { values }\end{array}$} & \multirow{2}{*}{ XG } & \multicolumn{2}{|c|}{ Remarks } \\
\hline & & & & & & $\mathbf{R Q}$ & Ho \\
\hline 1 & $\begin{array}{l}\text { It is convenient to listen to podcasts } \\
\text { at any place any time }\end{array}$ & 223.777 & 1.058 & 0.150 & 4.16 & Agree & NS \\
\hline 2 & $\begin{array}{l}\text { Ability to download and save podcasts } \\
\text { to Computer/mobiler devices } \\
\text { conveniently / easily }\end{array}$ & 241.277 & 1.674 & 0.060 & 4.09 & Agree & NS \\
\hline 3 & $\begin{array}{l}\text { Listening to podcasts on computer } \\
\text { instead of iPod or } \mathrm{mp} 3 \text { players }\end{array}$ & 245.989 & 0.633 & 0.327 & 4.00 & Agree & NS \\
\hline 4 & Listening to podcasts is interesting & 214.614 & 0.370 & 0.587 & 4.13 & Agree & NS \\
\hline 5 & $\begin{array}{l}\text { Podcasts are not good enough because } \\
\text { the presenters cannot be asked } \\
\text { questions }\end{array}$ & 302.870 & 1.179 & 0.083 & 4.20 & Agree & NS \\
\hline
\end{tabular}

Table 6. Mean ratings and analysis of variance (ANOVA) on students' experiences in using podcasts to learning English pronunciation $(N=376)$.

The results presented in table 6 show that the grand mean values of the 5 items in the table ranged from 4.00 to 4.20 which are all greater than the cut-off point value of 3.00 on the 5-point rating scale. This indicates that the respondents agreed that all 5 items in the table comprise the students' experiences in using podcasts while learning English pronunciation. The results of the analysis of variance (ANOVA) reveals that the p-values of the 5 items range from 0.060 to 0.587 which are greater than a 0.05 level of significance. This indicates that there are no significant differences in the mean ratings of the responses of students' experiences in using podcasts to learn English pronunciation at all levels of education on the 5 items.

The general view of the students on their experiences reveals that they enjoy listening to podcasts despite the fact that most of the podcasts are not interactive where they can ask the presenter questions. Craig, et al. (2007) and Windham (2007) also discovered that many L2 learners find the use of podcasts motivating. This is also in line with Knight (2010) and Thorne and Payne's (2005) findings. Newnham and Miller (2007) discovered that their respondents had a positive attitude toward using podcasts to learn.

\section{Research Question Seven}

What are the students' expectations in using podcasts to learn English pronunciation? 


\section{Hypothesis Seven}

There is no significant difference in the mean ratings of the responses of male and female students' expectations in using podcasts to learn English pronunciation.

The data for answering research question seven and testing hypothesis seven are presented in table 7 below.

\begin{tabular}{|c|c|c|c|c|c|c|c|}
\hline \multirow{2}{*}{ SN } & \multirow{2}{*}{$\begin{array}{l}\text { Students' expectations in using podcasts to } \\
\text { learn English pronunciation include: }\end{array}$} & \multirow{2}{*}{$\mathbf{X M}$} & \multirow{2}{*}{$\mathbf{X F}$} & \multirow[b]{2}{*}{$\mathbf{X G}$} & \multirow{2}{*}{ p-values } & \multicolumn{2}{|c|}{ Remarks } \\
\hline & & & & & & $\mathbf{R Q}$ & Ho \\
\hline 1 & The presenter's voice be clear & 4.17 & 4.05 & 4.16 & 0.110 & Agree & NS \\
\hline 2 & Podcasts be interactive & 4.15 & 4.22 & 4.23 & 0.204 & Agree & NS \\
\hline 3 & $\begin{array}{l}\text { Free/cheap internet access be provided by the } \\
\text { University administration }\end{array}$ & 4.23 & 4.27 & 4.35 & 0.074 & Agree & NS \\
\hline 4 & $\begin{array}{l}\text { Teachers of English phonetics and other related } \\
\text { courses be abreast of new technologies in } \\
\text { learning pronunciation }\end{array}$ & 4.09 & 4.05 & 4.07 & 0.652 & Agree & NS \\
\hline
\end{tabular}

Table 7. Mean ratings and t-test statistics on students' expectations in using podcasts to learn English pronunciation ( $N=376)$.

The results presented in table 7 show that the grand mean values of the 4 items in the table range from 4.07 to 4.35 which are all greater than the cut-off point value of 3.00 on the 5-point rating scale. This indicates that the respondents agreed that all the 4 items in the table comprise the students' expectations in using podcasts to learn English pronunciation. The results of Analysis of variance (ANOVA) reveal that the p-values of the 4 items range from 0.074 to 0.652 which are greater than a 0.05 level of significance. This indicates that there are no significant differences in the mean ratings of the responses of students' expectations in using podcasts to learn English pronunciation at all levels of education on the 4 items.

Access to the internet is the first step in the use of podcasts. With the high cost of internet facilities in Nigeria, many students who would wish to download podcasts may not be able to do so. Hence they desire that their respective university administration to provide them with cheap internet facilities to enable them to make effective use of podcasts. Due to financial contraints a very limited number of students would be able to download podcasts on a ragular basis. This may be one of the reasons why they expect their teachers to be abreast with new technologies for language learning since their teachers are presumably financially better off than they are.

\section{Conclusion}

This study sought to investigate students' experience and expectations regarding the use of podcasts to learn English pronunciation in the Igbo speech community. Most students testified to the fact that although their first knowledge of podcasts was independent of their teacher, they see podcasts as an effective tool that has reasonably improved their oral performance in English phonetics-related courses through the use of mobile gadgets. For effective use of podcasts in learning English pronunciation in Igboland, the following recommendations are made: 1 . the presenter's voice should be as clear as possible; 2 . as far as possible podcasts should be interactive; 3 . free/cheap internet access should be provided by the University administration, and 4 . teachers of English phonetics and other related courses should be abreast of new technologies to aid in learning pronunciation. Podcasts are therefore a pedagogic instrument that 
learners of English language in the Igbo speech community embrace in learning English as a second language in all levels of undergraduate education irrespective of gender.

\section{Notes}

[1]

\begin{tabular}{|l|l|}
\hline $\boldsymbol{X M}$ & Mean of Male Students \\
\hline $\boldsymbol{X F}$ & Mean of Female Students \\
\hline $\boldsymbol{X G}$ & Grand mean \\
\hline $\boldsymbol{R Q}$ & Research Question \\
\hline Ho & Hypothesis \\
\hline NS & Not Significant \\
\hline Level of significance & Significant \\
\hline S* & \\
\hline
\end{tabular}

\section{References}

Ashby, M., Figueroa-Clark, M., Seo, E., \& Yanagisawa, K. (2005). Innovations in practical phonetics teaching and learning. Proceedings of the Phonetics Teaching and Learning Conference, UCL.

Chan, W.M., Chen, I.R., \& Döpel, M. (2011). Podcasting in foreign language learning: Insights for podcast design from a developmental research project. In M. Levy, F. Blin, C. Bradin Siskin, \& O. Takeuchi (Eds.), WorldCALL: Global perspectives on computerassisted language learning. New York \& London: Routledge, pp. 19-37.

Craig, D., Paraiso, J., \& Patten, K.B. (2007). eLiteracy and literacy: Using ipods in the ESL classroom. Paper presented at the Society for Information Technology and Teacher EducationInternational Conference, Chesapeake, VA.

Derwing, T.M., \& Rossiter, M.J. (2002). ESL learners' perceptions of their pronunciation needs and strategies. System, 30, 155-166.

Ducate, L. \& Lomicka, L. (2009). Podcasting: An effective tool for honing language students' pronunciation? Language Learning \& Technology, 13, 66-86.

Eskenazi, M. (1999). Using automatic speech processing for foreign language pronunciation tutoring: Some issues and a prototype. Language Learning and Technology, 2(2), 62-76.

Hardison, D. (2004). Generalization of computer-assisted prosody training: Quantitative and qualitative findings. Language Learning \& Technology, 8, 34-52.

Hasan, M.M. \& Hoon, T.B. (2013). Podcast applications in language learning: A review of recent studies. English Language Teaching, 6. doi:10.5539/elt.v6n2p128 URL: http://ccsenet.org/journal/index.php/elt/article/view/23820. 
Kang, O. (2010). ESL learners' attitudes toward pronunciation instruction. In J.M. Levis \& K. LeVelle (Eds.), Proceedings of the 1st Pronunciation in Second Language Learning and Teaching Conference. Ames, IA: Iowa State University, pp. 105-118.

Knight, R-A. (2010). Sounds for study: Speech and language therapy students' use and perception of exercise podcasts for phonetics. International Journal of Teaching and Learning in Higher Education, 22, 269-276.

Lord, G. (2008). Podcasting communities and second language pronunciation. Foreign Language Annals, 41, 364-379.

Scales, J., Wennerstrom, A., Richard, D., \& Wu, S.H. (2006). Language learners' perceptions of accent. TESOL Quarterly, 40, 715-738.

Schmidt, J. (2008). Podcasting as a learning tool: German language and culture every day. Die Unterrichtspraxis/Teaching German, 41, 186-194.

Stenson, N., Downing, B., Smith, J., \& Smith, K. (1992). The effectiveness of computer assisted pronunciation training. CALICO Journal, 9, 5-18.

Tapscott, D. (2009). Grown up digital: How the net generation is changing your world. New York: McGraw-Hill.

Timmis, I. (2002). Native-speaker norms and international English: A classroom view. ELT Journal, 56, 240-249.

Thorne, S. \& Payne, S. (2005). Evolutionary trajectories, internet-mediated expression, and language education. The Pennsylvania State University http://language.la.psu.edu/ thorne/thorne_payne_calico2005.pdf

Windham, C. (2007). Confessions of a podcast junkie. EDUCAUSE Review, 42, 50-65. 